\title{
Putative involvement of adrenergic receptors in regulation of mussel (Perna canaliculus) larval settlement
}

\author{
TIM YOUNG ${ }^{1}$, ANDREA C. ALFARO $^{1 \star}$, CLARA SÁNCHEZ-LAZO $^{2} \&$ JOHN ROBERTSON $^{1}$ \\ ${ }^{1}$ Institute for Applied Ecology New Zealand, School of Applied Sciences, Faculty of Health and Environmental Sciences, \\ Auckland University of Technology, Auckland, New Zealand, and ${ }^{2}$ IFAPA Centro 'Agua del Pino', Consejería de Agricultura \\ y Pesca, Funta de Andalucia, Huelva, Spain
}

\begin{abstract}
Settlement responses were investigated for mussel (Perna canaliculus) larvae after exposure to catecholamines and their precursor metabolites. Settlement and mortality assays were conducted in Petri plates with chemical treatments (L-phenylalanine, L-tyrosine, L-DOPA, dopamine hydrochloride and epinephrine at various concentrations) and controls. The proteinogenic amino acids L-phenylalanine and L-tyrosine both were effective inducers $(\sim 65 \%)$ of larval settlement at $10^{-5} \mathrm{~mol} \mathrm{~L}^{-1}$ compared with controls $(4 \%)$. Exposure of larvae to L-DOPA, dopamine and epinephrine resulted in maximum settlement induction $\left(50,60\right.$ and $51 \%$, respectively) at $10^{-5} \mathrm{~mol} \mathrm{~L}^{-1}$. Larval mortalities were low (comparable to controls) across all concentrations of L-phenylalanine and L-tyrosine treatments whereas high mortalities ( $>60 \%)$ were observed for L-DOPA, dopamine and epinephrine at concentrations $\geq 10^{-4} \mathrm{~mol} \mathrm{~L}^{-1}$. Our results indicate that $P$. canaliculus larval settlement is under endogenous regulation by a catecholaminergic mechanism. Furthermore, the inductive effects of all tested metabolites in the epinephrine biosynthesis pathway point to a putative involvement of adrenergic-type receptors in regulation of larval settlement in this mussel species.
\end{abstract}

Key words: Catecholamines, dopamine, epinephrine, green-lipped mussels, larval settlement, Perna canaliculus

\section{Introduction}

The distributions of marine invertebrates at various spatial scales depend on their developmental mode and pre-metamorphic behaviour (Foggo et al. 2007). Most of these organisms develop in the plankton for varying durations depending on the species, which predetermines their maximum larval dispersal range. While free-swimming larvae are directly transported by ocean currents and near-surface wind forces (Cowen \& Sponaugle 2009), environmental factors regulating their behaviour also have a significant influence on the time spent in the planktonic phase e.g. food availability and quality, salinity, temperature and season (O'Connor et al. 2007; Gebauer et al. 2010). Once larvae reach a critical stage in their development, they become competent to metamorphose into their adult forms. In most cases, this change in body plan is preceded by movement of the organism from pelagic to benthic environments where larvae search for a suitable attachment substrate. This premetamorphic process is termed larval settlement and is mediated, at least partially, by chemoreception of environmental cues (Hadfield 2011). To gain insight into the endogenous signalling pathways involved in larval settlement and metamorphosis, pharmacologically active compounds can be applied in the laboratory to identify their regulatory effects.

Catecholamines (dopamine, norepinephrine and epinephrine) are involved in regulation of various cellular processes and behaviours in vertebrate and invertebrate systems. Within molluscan taxa, these neurotransmitters and hormones are involved in modulation of muscular and ciliary activities and have been implicated in the control of a wide range of critical functional parameters, including early

*Correspondence: Andrea C. Alfaro, Institute for Applied Ecology New Zealand, School of Applied Sciences, Faculty of Health and Environmental Sciences, Auckland University of Technology, Private Bag 92006, Auckland 1142, New Zealand. E-mail: andrea.alfaro@aut. ac.nz 
ontogenic behaviour (Croll \& Dickinson 2004), larval metamorphosis (Yang et al. 2014), sensory development (Wyeth \& Croll 2011), cardiac regulation (Kodirov 2011), feeding behaviour (Díaz-Ríos \& Miller 2005), reward-seeking behaviour (Barron et al. 2010), respiration (Tsyganov et al. 2004), waste removal (Carroll \& Catapane 2007), immune response (Zhou et al. 2011), locomotion (Filla et al. 2009) and reproduction (López-Sánchez et al. 2009). Dopamine, biosynthesized from the essential amino acid L-phenylalanine via L-tyrosine and L- $\beta-3$, 4-dihydroxyphenylalanine (L-DOPA) amino acid intermediates, can be converted to epinephrine via norepinephrine. While L-phenylalanine and L-tyrosine are usually assimilated through dietary means, some marine invertebrates have demonstrated an ability to take up free dissolved amino acids from seawater as an alternative or supplementary route (Söylemez et al. 2010; Leroy et al. 2012). In molluscs, endogenous levels of catecholamines and/or expression of their receptors vary depending on developmental stage and age (Kreiling et al. 2001), season or reproductive condition (López-Sánchez et al. 2009) and exposure to environmental stressors, such as air exposure, mechanical agitation, temperature and salinity (Chen et al. 2008; Qu et al. 2009). Thus, catecholamine metabolism is an important pathway linking a wide array of molluscan behaviours and their regulation by external stimuli.

Exogenous treatment of marine bivalves with catecholamines and/or their precursor metabolites has resulted in the induction of larval settlement and/or metamorphosis for a wide range of species, including representatives of scallops (Pectinoida), true oysters (Ostreoida), clams (Veneroida) and mussels (Mytiloida) (reviewed in Table I). Conversely, L-DOPA,

Table I. Larval responses of bivalve molluscs exposed to L-DOPA (DOP), dopamine (DA), norepinephrine (NE) and epinephrine (E) where: $s=$ settlement, $m=$ metamorphosis, $0=$ no effect, $1=$ inductive response. Missing data are represented by a hyphen.

\begin{tabular}{|c|c|c|c|c|c|c|}
\hline Group & Species & DOP & $\mathrm{DA}$ & NE & $E$ & References \\
\hline \multirow[t]{5}{*}{ Mussels } & Perna canaliculus & $1 \mathrm{~s}$ & $1 \mathrm{~s}$ & - & $1 \mathrm{~s}$ & Present study \\
\hline & Aulacomya maoriana & - & $1 \mathrm{~s}$ & - & $1 \mathrm{~s}$ & Alfaro et al. (2011) \\
\hline & Mytilus edulis & $1 \mathrm{~s}$ & - & - & - & Dobretsov \& Qian (2003) \\
\hline & Mytilus coruscus & - & $1 \mathrm{~m}$ & - & $1 \mathrm{~m}$ & Yang et al. $(2013,2014)$ \\
\hline & Mytilus galloprovincialis & $1 \mathrm{~m}$ & - & $1 \mathrm{~m}$ & $1 \mathrm{~s} / 1 \mathrm{~m}$ & $\begin{array}{l}\text { Satuito et al. (1999, 2005); García-Lavandeira } \\
\text { et al.(2005); Yang et al. (2008); Sánchez-Lazo } \\
\text { et al. (2012) }\end{array}$ \\
\hline \multirow[t]{3}{*}{ Pearl oysters } & Pinctada fucata martensii ${ }^{\star}$ & $0 \mathrm{~s}$ & $0 \mathrm{~s}$ & - & - & Yu et al. (2008) \\
\hline & Pinctada margaritifera & - & - & 0s & 0 s & Doroudi \& Southgate (2002) \\
\hline & Pinctada maxima & 0 s & $0 \mathrm{~s}$ & - & - & Zhao et al. (2003) \\
\hline \multirow[t]{9}{*}{ True oysters } & Saccostrea glomerata & - & - & - & $1 \mathrm{~s} / 1 \mathrm{~m}$ & O'Connor et al. (2008) \\
\hline & Ostrea angasi & $0 \mathrm{~m}$ & - & - & $1 \mathrm{~m}$ & O'Connor et al. (2009) \\
\hline & Ostrea edulis & - & - & - & $1 \mathrm{~s} / 1 \mathrm{~m}$ & García-Lavandeira et al. (2005) \\
\hline & Crassostrea virginica & $1 \mathrm{~s}$ & - & 0s & $0 \mathrm{~s} / 1 \mathrm{~m}$ & $\begin{array}{l}\text { Coon et al. (1986); Zimmer-Faust \& Tamburri } \\
\text { (1994); Grant (2009) }\end{array}$ \\
\hline & Crassostrea madrasensis & $1 \mathrm{~s} / 1 \mathrm{~m}$ & $0 \mathrm{~s} / 0 \mathrm{~m}$ & $0 \mathrm{~s} / 1 \mathrm{~m}$ & $0 \mathrm{~s} / 1 \mathrm{~m}$ & Murthy et al. (1999) \\
\hline & Crassostrea belcheri & $1 \mathrm{~s} / 1 \mathrm{~m}$ & - & $1 \mathrm{~m}$ & $1 \mathrm{~m}$ & Tan \& Wong(1995); Teh et al. (2010) \\
\hline & Crassostrea iredalei ${ }^{\star}$ & $1 \mathrm{~s}$ & - & $1 \mathrm{~s}$ & $1 \mathrm{~s}$ & Teh et al. (2011); Teh et al. (2012) \\
\hline & Crassostrea brasiliana & - & $1 \mathrm{~s}$ & $1 \mathrm{~s}$ & $1 \mathrm{~s} / 1 \mathrm{~m}$ & $\begin{array}{l}\text { Silveira et al. (2011); Alfaro et al. } \\
\text { (unpublished data) }\end{array}$ \\
\hline & Crassostrea gigas & $1 \mathrm{~s} / 1 \mathrm{~m}$ & $0-1 \mathrm{~s} \dagger$ & $0 \mathrm{~s} / 1 \mathrm{~m}$ & $0 \mathrm{~s} / 1 \mathrm{~m}$ & $\begin{array}{l}\text { Coon et al. (1985); Coon et al. (1986); Bonar } \\
\text { et al. (1990); Beiras \& Widdows (1995); Nicolas } \\
\text { et al. (1998) }\end{array}$ \\
\hline \multirow[t]{6}{*}{ Scallops } & Chlamys hastata & $0 \mathrm{~m}$ & - & - & - & Hodgson \& Burke 1988 \\
\hline & Chlamys varia ${ }^{\star}$ & - & - & - & $1 \mathrm{~s}$ & Mesías-Gansbiller et al. (2008) \\
\hline & Pecten maximus & $1 \mathrm{~m}$ & - & - & $1 \mathrm{~m}$ & $\begin{array}{l}\text { Cochard et al. (1989); Nicolas et al. (1996, } \\
\text { 1998); Chevolot et al. (1991) }\end{array}$ \\
\hline & Patinopecten yessoensis & - & - & - & $1 \mathrm{~m}$ & Kingzett et al. (1990) \\
\hline & Argopecten irradians & $1 \mathrm{~m}$ & - & $1 \mathrm{~m}$ & $1 \mathrm{~m}$ & Liu et al. (1998) \\
\hline & Argopecten purpuratus & - & - & - & $1 \mathrm{~s} / 1 \mathrm{~m}$ & Martinez et al. (1999) \\
\hline \multirow[t]{5}{*}{ Clams } & Ruditapes philippinarum* & $0 \mathrm{~m}$ & $0 \mathrm{~m}$ & $0 \mathrm{~m}$ & $0 \mathrm{~s} / 0-1 \mathrm{~m}$ & $\begin{array}{l}\text { Urrutia et al. (2004); García-Lavandeira et al. } \\
\text { (2005); Sumin et al. (2006) }\end{array}$ \\
\hline & Venerupis pullastra* & - & - & - & $1 \mathrm{~s} / 1 \mathrm{~m}$ & García-Lavandeira et al. (2005) \\
\hline & Meretrix meretrix & - & - & $1 \mathrm{~m}$ & $1 \mathrm{~m}$ & Wang et al. (2006) \\
\hline & Lutraria philippinarum * & $1 \mathrm{~s}$ & $1 \mathrm{~s}$ & - & $1 \mathrm{~s}$ & Alfaro et al. (unpublished data) \\
\hline & Coelomactra antiquata ${ }^{\star}$ & $1 \mathrm{~m}$ & - & - & $1 \mathrm{~m}$ & Gao \& Lui (2006) \\
\hline
\end{tabular}

^Species names are listed as described by the referenced literature. However, current taxonomic classifications may differ.

$\dagger$ Settlement behaviour was induced by a selective agonist (SKF 82,526) of D1 dopamine receptors. 
dopamine and/or epinephrine do not induce larval settlement in pearl oysters (Pterioida). Catecholamines also have little or no capacity to induce settlement/metamorphosis in the clam Ruditapes philippinarum (Adams \& Reeve, 1850). Furthermore, for some clades (e.g. the true oysters), settlement and metamorphosis appear to be under differential regulation by dopaminergic and adrenergic mechanisms, respectively. These species-specific responses imply differences in the biochemical mechanisms involved.

The New Zealand green-lipped mussel, Perna canaliculus (Gmelin, 1791), is a commercially important aquaculture species, and is farmed extensively for export markets (traded as Greenshell ${ }^{\mathrm{TM}}$ mussel). Over the past four decades, substantial research has been conducted on its adult biology, including spatial and temporal population distributions (Paine 1971; Alfaro 2006a; Alfaro et al. 2008), connectivity vectors (Alfaro \& Jeffs 2003; Alfaro et al. 2004; Alfaro et al. 2010), habitat preferences and community structure (Paine 1971; Alfaro 2006a; Alfaro et al. 2008), reproductive cycle (Hickman \& Illingworth 1980; Alfaro et al. 2001; Alfaro et al. 2003), diet and energetics (Gardner 2002; Alfaro 2006b; Safi \& Hayden 2010), behaviour (Kennedy 1976, 1984) and genetics (Gardner et al. 1996; Apte \& Gardner 2002; Wei et al. 2013). However, until recently, knowledge of the larval biology of this species was lacking. Partially driven by considerable interest in aquaculture development, current attention is being drawn towards the early life cycle physiology and behaviour of this important commercial species. Recent investigations on the larval settlement process and substrate preferences have identified a variety of exogenous stimuli that have the ability to regulate settlement behaviour. For example, crude chemical fractionates extracted from specific seaweeds with which the juvenile mussels are associated (Alfaro et al. 2006; Gribben et al. 2011), and from marine bacterial biofilms (Ganesan et al. 2010, 2012), have been shown to have settlementinducing and inhibitory effects. To gain insight into the endogenous control of settlement, we previously investigated effects of the neuroactive compounds $\gamma$ amino butyric acid, acetylcholine, atropine and potassium ions on larval settlement of this species (Young et al. 2011). Our results indicate that nicotinic-type acetylcholine receptors are involved in regulation of the settlement process. To further enhance our understanding of endogenous control, we report on the effects of catecholamines and their precursor metabolites on the larval settlement of $P$. canaliculus.

\section{Materials and methods}

Chemical treatments

Several compounds involved in epinephrine biosynthesis were tested for their abilities to induce settlement of Perna canaliculus larvae. These chemicals included L-phenylalanine (AppliChem), L-tyrosine (AppliChem), L-DOPA (Sigma-Aldrich), dopamine hydrochloride (Sigma-Aldrich) and epinephrine (Sigma-Aldrich). Stock solutions ( $10 \times$ concentrates) of each treatment level were prepared by dissolving compounds in $0.45 \mu \mathrm{m}$ filtered seawater (FSW) immediately prior to settlement assays. These concentrations were chosen based on a pilot study and our experience with other mussel species (Alfaro et al. 2011; Sánchez-Lazo et al. 2012).

\section{Settlement assays}

Settlement-competent veliger larvae (19-23 days post-fertilization) were obtained from Cawthron Institute and Shellfish Production and Technology New Zealand Limited (SPATnz), both in Nelson, New Zealand. The larvae were transported in moist and cold containers to the Auckland University of Technology (AUT) laboratory, Auckland, New Zealand. Upon arrival, the larvae were transferred into a $2 \mathrm{~L}$ beaker containing $1 \mathrm{~L}$ of FSW. After 30$60 \mathrm{~min}$, healthy swimming larvae were decanted into another beaker, and topped up with FSW to make up a concentration of 20-30 larvae $\mathrm{mL}^{-1}$. Settlement assays were conducted in sterile polystyrene Petri plates $(60 \times 14 \mathrm{~mm})$, with 10 replicates per treatment at $17 \pm 1^{\circ} \mathrm{C}$ under ambient light conditions. Chemical treatment assays consisted of $8 \mathrm{~mL}$ FSW, $1 \mathrm{~mL}$ larval solution (i.e. 20-30 larvae per Petri plate) and $1 \mathrm{~mL}$ concentrated (10x) treatment solution. Due to limited larval availability, several experiments were conducted to test the compounds for settlement-inducing ability with mussels from different larval batches. Thus, to standardize the data across experiments, a new set of controls $(9 \mathrm{~mL}$ FSW and $1 \mathrm{~mL}$ larval solution) was used for each batch cohort. Larval settlement and mortality were recorded for all plates after 48 hours, as is optimal for this species (Young et al. 2011; Ganesan et al. 2012). Under a dissecting microscope at $20-45 \times$ magnification, a $200 \mu \mathrm{L}$ displacement pipette was depressed and brought within close proximity (0.5$1.5 \mathrm{~mm}$ ) to each larva, and gentle suction was applied. Individuals that maintained firm attachment to the substratum were considered settled, and those moving freely with no resistance were considered unsettled. This technique provides a reliable and reproducible way to identify attached/unattached 
larvae and is well-established in the literature (Ganesan et al. 2010, 2012; Alfaro et al. 2011; Young et al. 2011; Sánchez-Lazo et al. 2012; Wilkens et al. 2012; $\mathrm{McDonald}$ et al. 2014). Furthermore, we have found this method to be consistently more reliable than other methods (e.g. decanting the medium or mechanical agitation of the substrate) for larval settlement assessment. Percentage settlement was calculated as the proportion of settled larvae from the number initially placed in each plate. In many cases, settlement could be detected visually by the presence of thin transparent mucous-like threads, but settlement was always verified by suction.

\section{Mortality assays}

To determine acute toxicity effects, mortalities were recorded within the settlement assays under a stereo microscope at $20-45 \times$ magnification. Larvae that showed signs of movement of the velum, foot or gut were considered alive. Since live larvae often were inanimate for periods of more than $15 \mathrm{~min}$, neutral red (a vital stain) was used to corroborate mortality detection (Zetsche \& Meysman 2012). A 120 ppm solution of neutral red was prepared in FSW and diluted in the experimental medium to give a final stain concentration of $20 \mathrm{ppm}$. After $30 \mathrm{~min}$, larvae were again viewed at $20 \times$ magnification under a stereo microscope. Larvae that did not incorporate the stain into their tissues were considered dead. Percentage mortality was calculated based on the initial number of larvae within each plate.

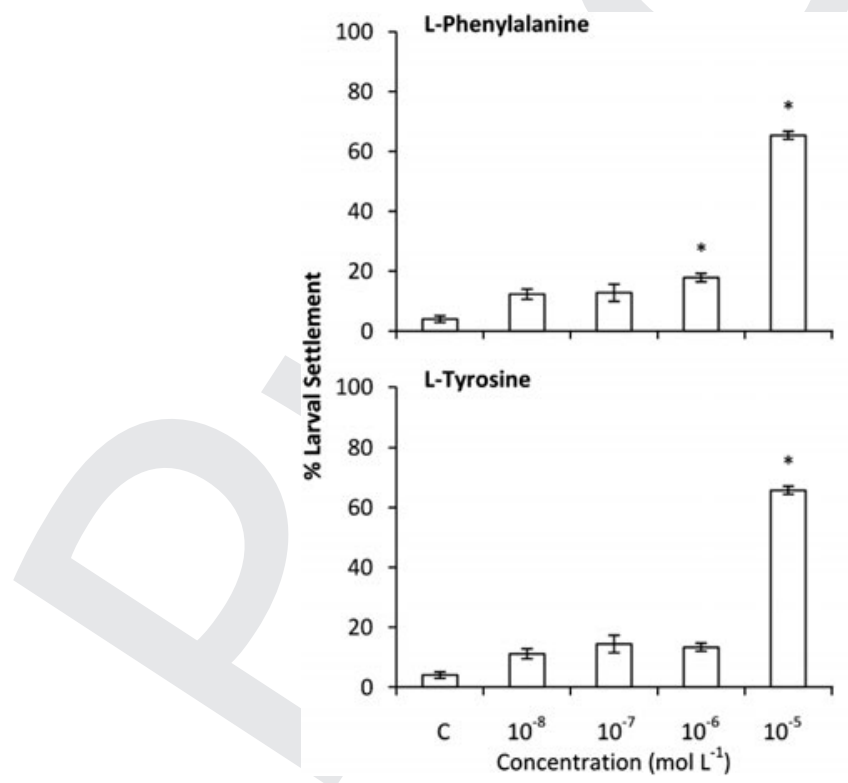

\section{Statistics}

All percentage larval settlement and mortality data were analysed using the non-parametric KruskalWallis H-test and followed by Dunn's multiple comparison tests. The level of significance chosen was 0.05 for all statistical tests. Data were analysed using the Minitab version 16 statistical software package.

\section{Results}

L-phenylalanine and L-tyrosine induced larval settlement with similar dose-dependent response trends (Figure 1). For each amino acid, significant differences (Kruskal-Wallis) were detected among concentrations (Table II). Compared with controls, L-phenylalanine was an effective inducer at $10^{-7}$, $10^{-6}$ and $10^{-3} \mathrm{~mol} \mathrm{~L}^{-1}$ (Dunn's tests: $P<0.05$ ). Treatment with L-tyrosine gave comparable results, but also induced settlement at $10^{-8} \mathrm{~mol} \mathrm{~L}^{-1}$ (Dunn's tests: $P<0.05$ ). However, inductive effects of each compound at concentrations below $10^{-5} \mathrm{~mol}$ $\mathrm{L}^{-1}$ were minimal. Toxicity responses of larvae to L-phenylalanine and L-tyrosine revealed that neither amino acid caused significant mortality compared with controls $(<20 \%)$.

Induction of settlement also was achieved with L-DOPA, dopamine and epinephrine treatments (Figure 2) with significant differences (KruskalWallis) detected among concentrations (Table II). Although the range of treatment concentrations varied among the compounds tested, exposure of

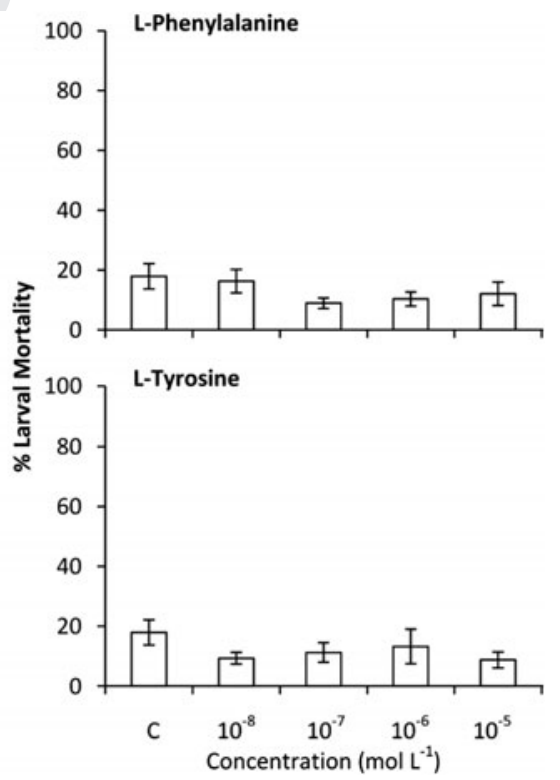

Figure 1. Percentage $( \pm S E)$ settlement (graphs on left) and mortality (graphs on right) of mussel larvae exposed to L-phenylalanine and L-tyrosine at different concentrations. Control assays are denoted ' $\mathrm{C}$ ' on the $x$-axes and asterisks $\left({ }^{\star}\right)$ represent significant differences against controls resulting from Dunn's multiple comparisons. 
larvae to L-DOPA, dopamine and epinephrine resulted in maximum induction (50,60 and 51\% respectively) at $10^{-5} \mathrm{~mol} \mathrm{~L}^{-1}$. In each case, higher concentrations resulted in a decrease in inductive effect with complete inhibition observed at $10^{-3} \mathrm{~mol}$ $\mathrm{L}^{-1}$ for L-DOPA and epinephrine. At $10^{-5} \mathrm{~mol} \mathrm{~L}^{-1}$, mortality responses to all three compounds generally were low $(-20 \%)$, but were high $(\geq 60 \%)$ at $10^{-4}$ mol L ${ }^{-1}$ (Figure 2).

Table II. Kruskal-Wallis statistics of larval settlement and mortality after exposure to different concentrations of catecholamines and their precursor amino acids.

\begin{tabular}{lccccccr}
\hline & \multicolumn{3}{c}{ Settlement } & & \multicolumn{3}{c}{ Mortality } \\
\cline { 2 - 3 } \cline { 6 - 7 } Compound & $d f$ & $H$ & $P$-value & & $d f$ & $H$ & $P$-value \\
\hline L-phenylalanine & 4 & 36.32 & $<0.001$ & & 4 & 4.98 & 0.290 \\
L-tyrosine & 4 & 35.31 & $<0.001$ & 4 & 3.96 & 0.411 \\
L-DOPA & 3 & 32.56 & $<0.001$ & & 3 & 31.80 & $<0.001$ \\
Dopamine & 3 & 20.06 & $<0.001$ & 3 & 25.47 & $<0.001$ \\
Epinephrine & 3 & 33.54 & $<0.001$ & 3 & 32.16 & $<0.001$ \\
\hline
\end{tabular}
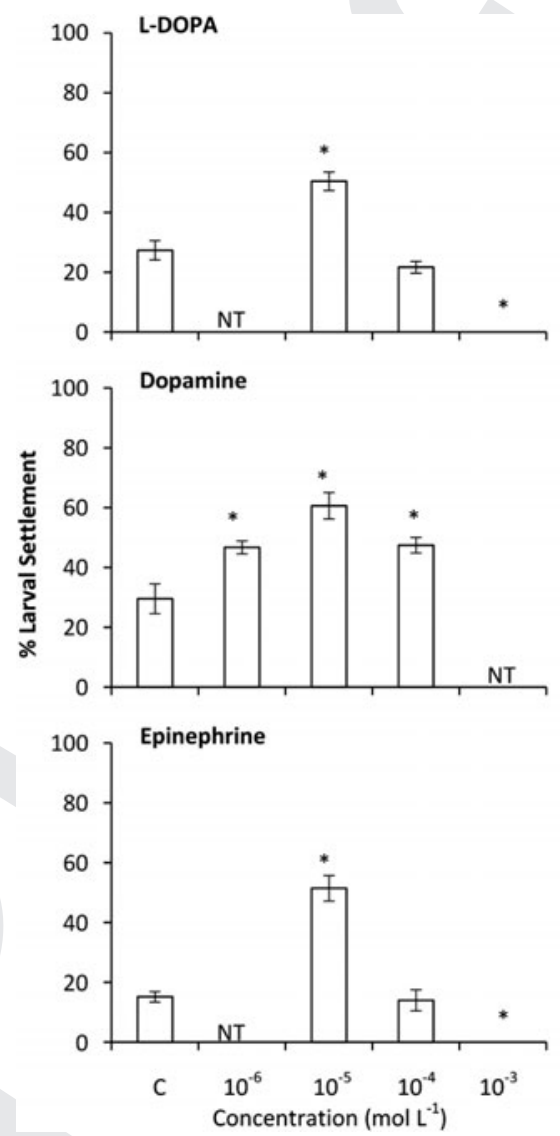

\section{Discussion}

The proteinogenic amino acids, L-phenylalanine and L-tyrosine, typically induced greater peak settlement than L-DOPA, dopamine or epinephrine treatments. For these amino acids, highest settlement $(65 \%)$ was achieved at $10^{-5} \mathrm{~mol} \mathrm{~L}^{-1}$. In a second trial (data not shown), we also tested the effects of L-phenylalanine and L-tyrosine at $10^{-4}$ and $10^{-3} \mathrm{~mol} \mathrm{~L}^{-1}$ however both concentrations were extremely toxic to animals ( $100 \%$ mortality). The amino acid L-DOPA and the catecholamines dopamine and epinephrine also demonstrated significant capacities to induce Perna canaliculus larval settlement. While the tested concentrations differed among treatments, settlement responses were highest (c. $\geq 2 \times$ control values) at $10^{-5} \mathrm{~mol} \mathrm{~L}^{-1}$ for all three compounds. This peak in settlement was accompanied by low mortality. Although control data differed slightly due to batch variability, the mean percentage settlements at $10^{-5} \mathrm{~mol} \mathrm{~L}^{-1}$ across all treatments investigated in this study were similar and had a maximal settlement induction capacity range of $50-65 \%$ with minimal toxic effects.
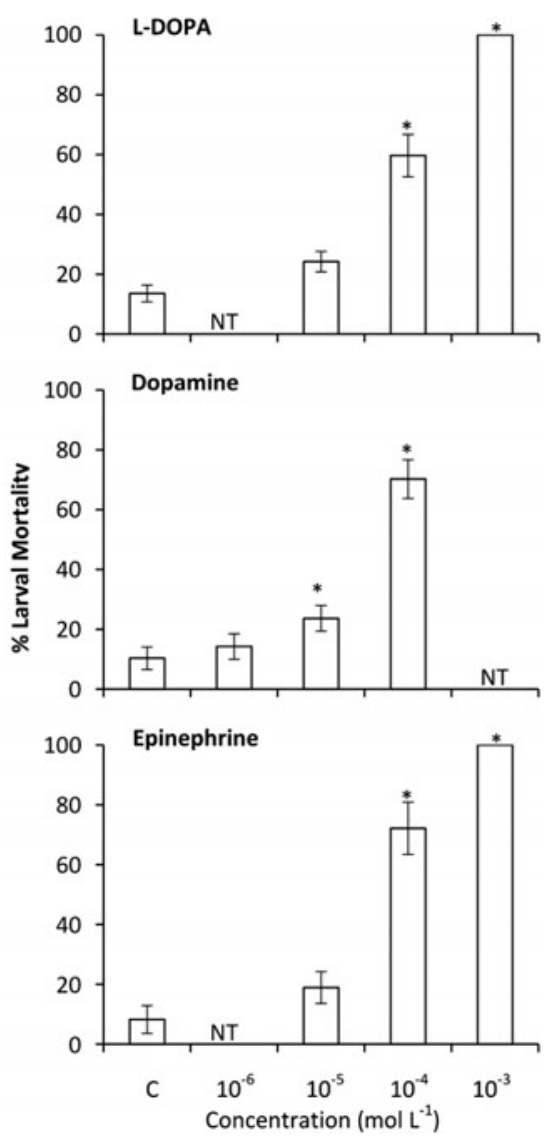

Figure 2. Percentage $( \pm \mathrm{SE}$ ) settlement (graphs on left) and mortality (graphs on right) of mussel larvae exposed to different concentrations of L-DOPA, dopamine and epinephrine treatments. Concentrations that were not tested for some compounds are denoted with the abbreviation NT. Control assays are denoted 'C' on the $x$-axes and asterisks $\left({ }^{\star}\right)$ represent significant differences against within-trial controls resulting from Dunn's multiple comparisons. 
While the mechanism of L-phenylalanine and L-tyrosine induction is currently unknown, we tentatively hypothesize that their ability to induce settlement is via conversion to their neuroactive catecholamine derivatives. In support, it is wellestablished that treatment of marine molluscs with dopamine precursors enhances levels of endogenous catecholamines. For example, in the mussel Mytilus edulis (Linnaeus, 1758) and the clam Mercenaria mercenaria (Linnaeus, 1758), dopamine biosynthesis in pedal ganglia is stimulated by exogenous incubation with L-tyrosine (Boadle-Biber \& Roth 1972; Zhu et al. 2005a). Elevated dopamine and norepinephrine levels, and an increase in the numbers of catecholamine-containing cells, have also been observed in the nudibranch Phestilla lugubris (Bergh, 1870) following treatment of whole organisms with the L-tyrosine-dopamine intermediate L-DOPA (Pires et al. 2000). In addition, positive immunolabelling of tyrosine hydroxylase-containing cells (the enzyme that catalyses the synthesis of L-DOPA from L-tyrosine) within the velar tissue of Crepidula fornicata (Linnaeus, 1758) indicates the presence of a catecholamine-based settlement regulatory mechanism via innervations of propulsive cilia (Penniman et al. 2013). However, since L-phenylalanine and L-tyrosine are involved in other metabolic pathways, such as synthesis of thyroxine (a thyroid hormone implicated in regulation of echinoderm development) (Saito et al. 2012), tyramine, a biogenic amine implicated in the regulation of bryozoan larval settlement (Shimizu et al. 2000), an octopamine, norepinephrine analogue with dopaminergic and adrenergic activity (Dahlström \& Elwig 2006) and morphine (Zhu 2005b), we recognize that alternative mechanisms, not yet identified, may be involved in their settlement-inducing effects. Thus, by employing a suite of traditional and contemporary methods (e.g. immunohistochemistry, confocal microscopy, metabolomics and proteomics), we are currently working on testing our hypothesis to identify the precise mode/s of action for these proteinogenic amino acids.

It has previously been demonstrated that endogenous dopamine, norepinephrine and epinephrine, or proteins involved in their synthesis, are present in appreciable quantities and exhibit unique profiles during early development of marine invertebrates (Anitole-Misleh \& Brown 2004; Croll 2006; Huan et al. 2012). Levels of endogenous dopamine peak during settlement and metamorphosis in larvae of the scallop Pecten maximus (Linnaeus, 1758) (CannMoisan et al. 2002), and a steady increase in norepinephrine has been detected leading up to metamorphosis in the oyster Crassostrea gigas (Thunberg, 1793) (Coon \& Bonar 1986). Also during this phase of larval development, increases in numbers of catecholamine-containing cells and changes to their distributions within tissues occur in the scallop Placopecten magellanicus (Gmelin, 1791) and the mussel M. edulis (Croll et al. 1997). While such classical neurotransmitters are known to have regulatory roles through animal ontogenesis prior to development of the nervous system (Buznikov et al. 1996), these correlative evidences between neurotransmitter expression and post-ganglionic development suggest that the molecular mechanisms of settlement and metamorphosis are under dopaminergic and adrenergic neuronal control. Stimulation of these processes by manipulation of endogenous transmitter levels, or activation of target receptors, provides further evidence of catecholamine involvement.

An early model for catecholamine-induced settlement and metamorphosis in oysters has been proposed to involve regulation by dopaminergic behavioural and adrenergic morphogenetic pathways, respectively (Coon et al. 1985; Coon \& Bonar 1986; Bonar et al. 1990). In an effort to identify the specific receptor/s responsible for catecholamineinduced settlement and metamorphosis in bivalves, results of pharmacological and immunohistochemical investigations provide evidence to suggest the involvement of $\beta$-adrenergic-type receptors in the central nervous systems of the clam Meretrix meretrix (Linnaeus, 1758) (Wang et al. 2006) and $\alpha$-adrenergictype receptors in the mussel Mytilus coruscus Gould, 1861 (B. Yang et al. 2014). While the role, and even presence, of epinephrine in the neural tissues of marine invertebrates has been debated (Stefano \& Kream 2010), analysis of larval gene expression (DDRT-PCR) in the clam Ruditapes philippinarum (Adams \& Reeve, 1850) revealed high levels of differentially expressed transcripts compared with control organisms after induction of settlement/ metamorphosis with epinephrine (Sumin et al. 2006). In addition, Yang et al. (2012) recently characterized an adrenergic-like receptor gene (ARcga) in larvae of the oyster Crassostrea angulata (Lamark, 1819) and performed a temporal analysis of its expression during larval development through real-time qPCR and whole mount in situ hybridization. A clear peak in ARcga expression was observed during settlement and metamorphic competency and also after bath application of whole larvae in epinephrine (Yang et al. 2012). In a subsequent investigation to identify downstream components of the epinephrine-induced pathway, Yang et al. (2014) also provided evidence for the involvement of Receptor for Activated C Kinase 1 (RACK1) during larval metamorphosis of $C$. angulata and demonstrated that its gene and protein 
expressions were up-regulated by epinephrine treatment. RACK1 is known to interact with protein kinase $\mathrm{C}$ (PKC) and cyclic adenosine monophosphate (cAMP), both of which have been implicated as endogenous regulators of marine invertebrate larval settlement or metamorphosis ( $\mathrm{Li}$ et al. 2008). It appears that interpretations of data generated from pharmacological-based approaches to investigate regulatory biochemical pathways and neuronal control of larval settlement are increasingly being supported by the results from molecular studies. Thus, mounting evidence indicates that at least for some bivalve species, including $P$. canaliculus, adrenergic receptors have an important role to play in the signal transduction mechanism of settlement and/or metamorphosis.

Furthermore, biogenic amines naturally present in seawater may deliver an exogenous mechanism which target endogenous or epithelial-bound larval receptors. For example, some marine biofilms release settlement-promoting compounds that are structurally related to L-DOPA (Railkin 2004). The bloom-forming macroalga Ulvaria obscura (Kützing) ex P. Gayral ex C. Blinding is also known to release large amounts of dopamine into surrounding seawater (up to $550 \mu \mathrm{M}$ ) upon rehydration following emersion during low tide (Van Alstyne et al. 2011, 2013). At these environmentally relevant concentrations, there is evidence to suggest that the dopamine produced can affect cohabitating algal and invertebrate communities in the intertidal and shallow subtidal zones (Van Alstyne et al. 2014). While $U$. obscurra is not found in New Zealand, it is possible that catecholamines released from algae or marine biofilms may provide an environmental source.

We previously investigated the effects of epinephrine and/or precursor metabolites in two other marine mussels, Aulacomya maoriana (Iredale, 1915) (Alfaro et al. 2011) and Mytilus galloprovincialis Lamark, 1819 (Sánchez-Lazo et al. 2012), which revealed similar settlement responses to those found for $P$. canaliculus in the present study. These similarities are suggestive of a common biochemical mechanism of larval settlement among mussel species, but more comprehensive comparative studies will be needed to identify patterns among other molluscan clades.

The identification of endogenous regulatory mechanisms of larval development rates, settlement behaviour and morphogenetic processes has wide ecological and economic implications. The distributions and survival of sessile marine invertebrates depend largely on their ability to successfully select suitable habitats and transition to their juvenile forms. Exogenous stimuli (physical, chemical or biological) that have the ability to affect these mechanisms could cause dramatic changes in population dynamics and species compositions. For example, a wide range of anthropogenic pollutants with pharmacological activity are increasingly being detected in a variety of marine habitats, from populated urban areas to remote and exposed coastlines. Caffeine provides an interesting case study due to its familiarity, high global usage and widespread abundance in environmental waters. As a central nervous system stimulant, caffeine is known to cause neuronal release of acetylcholine and dopamine, increase norepinephrine synthesis and enhance dopaminergic neurotransmission (Acquas et al. 2002; Ferré 2010). Having being detected in marine environments at levels exceeding those which are chronically toxic for shellfish (Siegener \& Chen 2002; Aguirre-Marítnez et al. 2013; Beretta et al. 2014), potential effects on benthic community structure via regulation of larval behaviour and development rates seems plausible. Characterization of endogenous developmental mechanisms provides a predictive ability to hypothesize and test possible latent effects of particular anthropogenic pollutants based on their known pharmacological activities. On a more positive note, the identification of receptors involved in settlement and metamorphosis for species with commercial value offers potential means to improve production by enhancing settlement rates and synchronizing metamorphosis during hatchery culture. As one of the key bottlenecks in the growing mollusc aquaculture industry, the ability to stimulate these processes would be highly advantageous.

\section{Acknowledgements}

We are thankful to Dan McCall (SPATnz) and Bridget Alexander (Cawthron Institute), for providing mussel larvae for these experiments. We are grateful to the laboratory technicians in the School of Applied Sciences, Auckland University of Technology, for their ongoing assistance. We also thank Annapoorna M. Ganesan, John Brooks, Colleen Higgins, and the rest of the Aquaculture Biotechnology Group at AUT for many fruitful discussions.

\section{Funding}

This research was supported by a Foundation for Research Science and Technology Pre-Seed grant (FRST-PSAF UOWX0716) and an AUT Research Grant to A.C. Alfaro.

\section{References}

Acquas E, Tanda G, Di Chiara G. 2002. Differential effects of caffeine on dopamine and acetylcholine transmission in brain areas of drug-naive and caffeine-pretreated rats. Neuropsychopharmacology 27:182-93. 
Aguirre-Marítnez GV, Buratti S, Fabbri E, DelValls AT, MartínDíaz ML. 2013. Using lysosomal membrane stability of haemocytes in Ruditapes philippinarum as a biomarker of cellular stress to assess contamination by caffeine, ibuprofen, carbamazepine and novobiocin. Journal of Environmental Sciences 25:1408-18.

Alfaro AC, Jeffs AG, Hooker SH. 2001. Reproductive behavior of the green-lipped mussel, Perna canaliculus, in northern New Zealand. Bulletin of Marine Science 69:1095-108.

Alfaro AC, Jeffs AG. 2003. Variability in mussel settlement on suspended ropes placed at Ahipara Bay, Northland, New Zealand. Aquaculture 216:115-26.

Alfaro AC, Jeffs AG, Hooker SH. 2003. Spatial variability in reproductive behaviour of green-lipped mussel populations of northern New Zealand. Molluscan Research 23:223-38.

Alfaro AC, Jeffs AG, Creese RG. 2004. Bottom-drifting algal/ mussel spat associations along a sandy coastal region in northern New Zealand. Aquaculture 241:269-90.

Alfaro AC. 2006a. Population dynamics of the green-lipped mussel, Perna canaliculus, at various spatial and temporal scales in northern New Zealand. Journal of Experimental Marine Biology and Ecology 334:294-315.

Alfaro AC. 2006b. Evidence of cannibalism and bentho-pelagic coupling within the life cycle of the mussel, Perna canaliculus. Journal of Experimental Marine Biology and Ecology 329:206-17.

Alfaro AC, Copp BR, Appleton DR, Kelly S, Jeffs AG. 2006. Chemical cues promote settlement in larvae of the green-lipped mussel, Perna canaliculus. Aquaculture International 14: 405-12.

Alfaro AC, Webb SC, Barnaby C. 2008. Variability of growth, health, and population turnover within mussel beds of Perna canaliculus in northern New Zealand. Marine Biology Research 4:376-83.

Alfaro AC, McArdle B, Jeffs AG. 2010. Temporal patterns of arrival of beachcast green-lipped mussel (Perna canaliculus) spat harvested for aquaculture in New Zealand and its relationship with hydrodynamic and meteorological conditions. Aquaculture 302:208-18.

Alfaro AC, Young T, Ganesan AM. 2011. Regulatory effects of mussel (Aulacomya maoriana Iredale 1915) larval settlement by neuroactive compounds, amino acids and bacterial biofilms. Aquaculture 322-323:158-68.

Anitole-Misleh KG, Brown KM. 2004. Developmental regulation of catecholamine levels during sea urchin embryo morphogenesis. Comparative Biochemistry and Physiology - Part A: Molecular \& Integrative Physiology 137:39-50.

Apte S, Gardner JPA. 2002. Population genetic subdivision in the New Zealand greenshell mussel (Perna canaliculus) inferred from single-strand conformation polymorphism analysis of mitochondrial DNA. Molecular Ecology 11:1617-28.

Barron AB, Sovik E, Cornish JL. 2010. The roles of dopamine and related compounds in reward-seeking behavior across animal phyla. Frontiers in Behavioral Neuroscience 4:163.

Beiras R, Widdows J. 1995. Effect of the neurotransmitters dopamine, serotonin and norepinephrine on the ciliary activity of mussel (Mytilus edulis) larvae. Marine Biology 122:597-603.

Beretta M, Britto V, Tavares TM, da Silva SMT, Pletsch AL. 2014. Occurrence of pharmaceutical and personal care products (PPCPs) in marine sediments in the Todos os Santos Bay and the north coast of Salvador, Bahia, Brazil. Journal of Soils and Sediments 14:1278-86.

Boadle-Biber MC, Roth RH. 1972. Factors modifying the synthesis of dopamine from tyrosine in pedal ganglia of Mercenaria mercenaria (mollusca). Comparative and General Pharmacology 3:61-74.
Bonar DB, Coon SL, Walch M, Weiner RM, Fitt W. 1990. Control of oyster settlement and metamorphosis by endogenous and exogenous chemical cues. Bulletin of Marine Science 46:484-98.

Buznikov G, Shmukler Y, Lauder J. 1996. From oocyte to neuron: Do neurotransmitters function in the same way throughout development? Cellular and Molecular Neurobiology 16:533-59.

Cann-Moisan C, Nicolas L, Robert R. 2002. Ontogenic changes in the contents of dopamine, norepinephrine and serotonin in larvae and postlarvae of the bivalve Pecten maximus. Aquatic Living Resources 15:313-18.

Carroll MA, Catapane EJ. 2007. The nervous system control of lateral ciliary activity of the gill of the bivalve mollusc, Crassostrea virginica. Comparative Biochemistry and Physiology Part A: Molecular \& Integrative Physiology 148:445-50.

Chen M, Yang H, Xu B, Wang F, Liu B. 2008. Catecholaminergic responses to environmental stress in the hemolymph of zhikong scallop Chlamys farreri. Journal of Experimental Zoology Part A: Ecological Genetics and Physiology 309: 289-96.

Chevolot L, Cochard J-C, Yvin J-C. 1991. Chemical induction of larval metamorphosis of Pecten maximus with a note on the nature of naturally occurring triggering substances. Marine Ecology Progress Series 74:83-89.

Cochard J-C, Chevolot L, Yvin J-C, Chevolot-Magueur AM. 1989. Induction de la métamorphose de la coquille SaintJacques Pecten maximus L. par des dérives de la tyrosine extraits de l'algue Delesseria sanguinea Lamouroux ou synthétiques. Haliotis 19:129-54.

Coon SL, Bonar DB, Weiner RM. 1985. Induction of settlement and metamorphosis of the pacific oyster, Crassostrea gigas (Thunberg), by L-DOPA and catecholamines. Journal of Experimental Marine Biology and Ecology 94:211-21.

Coon SL, Bonar DB. 1986. Norepinephrine and dopamine content of larvae and spat of the Pacific oyster, Crassostrea gigas. The Biological Bulletin 171:632-39.

Coon SL, Bonar DB, Weiner RM. 1986. Chemical production of cultchless oyster spat using epinephrine and norepinephrine. Aquaculture 58:255-62.

Cowen RK, Sponaugle S. 2009. Larval dispersal and marine population connectivity. Annual Review of Marine Science $1: 443-66$

Croll RP, Jackson DL, Voronezhskaya EE. 1997. Catecholaminecontaining cells in larval and postlarval bivalve molluscs. Biological Bulletin 193:116-24.

Croll RP, Dickinson AJG. 2004. Form and function of the larval nervous system in molluscs. Invertebrate Reproduction \& Development 46:173-87.

Croll RP. 2006. Development of embryonic and larval cells containing serotonin, catecholamines, and FMRFamiderelated peptides in the gastropod mollusc Phestilla sibogae. The Biological Bulletin 211:232-47.

Dahlström M, Elwing H. 2006. Adrenoceptor and other pharmacoactive compounds as putative antifoulants. Marine Molecular Biotechnology 42:171-202.

Díaz-Ríos M, Miller MW. 2005. Rapid dopaminergic signaling by interneurons that contain markers for catecholamines and GABA in the feeding circuitry of Aplysia. Journal of Neurophysiology 93:2142-56.

Dobretsov SV, Qian PY. 2003. Pharmacological induction of larval settlement and metamorphosis in the blue mussel Mytilus edulis L. Biofouling 19:57-63.

Doroudi MS, Southgate PC. 2002. The effect of chemical cues on settlement behaviour of blacklip pearl oyster (Pinctada margaritifera) larvae. Aquaculture 209:117-24. 
Ferré S. 2010. Role of the central ascending neurotransmitter systems in the psychostimulant effects of caffeine. Journal of Alzheimer's Disease 1:S35-49.

Filla A, Hiripi L, Elekes K. 2009. Role of aminergic (serotonin and dopamine) systems in the embryogenesis and different embryonic behaviors of the pond snail, Lymnaea stagnalis. Comparative Biochemistry and Physiology Part C: Toxicology \& Pharmacology 149:73-82.

Foggo A, Bilton DT, Rundle SD. 2007. Do developmental mode and dispersal shape abundance-occupancy relationships in marine macroinvertebrates? Journal of Animal Ecology 76: 695-702.

Ganesan AM, Alfaro AC, Brooks JD, Higgins CM. 2010. The role of bacterial biofilms and exudates on the settlement of mussel (Perna canaliculus) larvae. Aquaculture 306:388-92.

Ganesan AM, Alfaro AC, Higgins CM, Duxbury M, Brooks JD. 2012. Characterization of biofilm exudates and their effects on settlement of mussel (Perna canaliculus) larvae. Journal of Experimental Marine Biology and Ecology 434:34-46.

Gao R-C, Lui W-B. 2006. Induction of larval settlement and metamorphosis of Coelomactra antiquata using some chemicals. Journal of Fisheries of China 30:597-602.

García-Lavandeira M, Silva A, Abad M, Pazos AJ, Sánchez JL, Pérez-Parallé ML. 2005. Effects of GABA and epinephrine on the settlement and metamorphosis of the larvae of four species of bivalve molluscs. Journal of Experimental Marine Biology and Ecology 316:149-56.

Gardner JPA, Eyles RF, Pande A. 1996. Biochemical-genetic variation in a wild and a cultured population of the greenshell mussel, Perna canaliculus. New Zealand Journal of Marine and Freshwater Research 30:435-41.

Gardner JPA. 2002. Effects of seston variability on the clearance rate and absorption efficiency of the mussels Aulacomya maoriana, Mytilus galloprovincialis and Perna canaliculus from New Zealand. Journal of Experimental Marine Biology and Ecology 268:83-101.

Gebauer P, Paschke K, Anger K. 2010. Seasonal variation in the nutritional vulnerability of first-stage larval porcelain crab, Petrolisthes laevigatus (Anomura: Porcellanidae) in southern Chile. Journal of Experimental Marine Biology and Ecology 386:103-12.

Grant MN. 2009. Chemical induction of settlement in larvae of the eastern oyster Crassostrea virginica (Gmelin). Master's Thesis. University of Maryland, United States of America. 60 pages.

Gribben PE, Jeffs AG, de Nys R, Steinberg PD. 2011. Relative importance of natural cues and substrate morphology for settlement of the New Zealand Greenshell ${ }^{\mathrm{TM}}$ mussel, Perna canaliculus. Aquaculture 319:240-46.

Hadfield MG. 2011. Biofilms and marine invertebrate larvae: What bacteria produce that larvae use to choose settlement sites. Annual Review of Marine Science 3:453-70.

Hickman RW, Illingworth J. 1980. Condition cycle of the greenlipped mussel Perna canaliculus in New Zealand. Marine Biology 60:27-38.

Hodgson CA, Burke RD. 1988. Development and larval morphology of the spiny scallop, Chlamys hastata. The Biological Bulletin 174:303-18.

Huan P, Wang H, Dong B, Liu B. 2012. Identification of differentially expressed proteins involved in the early larval development of the Pacific oyster Crassostrea gigas. Journal of Proteomics 75:3855-65.

Kennedy VS. 1976. Desiccation, higher temperatures and upper intertidal limits of three species of sea mussels (Mollusca: Bivalvia) in New Zealand. Marine Biology 35:127-37.

Kennedy VS. 1984. Crawling and clustering behaviour of 3 species of intertidal mussels in New Zealand. New Zealand Journal of Marine \& Freshwater Research 18:417-23.
Kingzett BC, Bourne N, Leask K. 1990. Induction of metamorphosis of the Japanese scallop Patinopecten yessoensis Jay. Journal of Shellfish Research 9:119-26.

Kodirov SA. 2011. The neuronal control of cardiac functions in Molluscs. Comparative Biochemistry and Physiology - Part A: Molecular \& Integrative Physiology 160:102-16.

Kreiling JA, Jessen-Eller K, Miller J, Seegal RF, Reinisch CL. 2001. Early development of the serotonergic and dopaminergic nervous system in Spisula solidissima (surf clam) larvae. Comparative Biochemistry and Physiology - Part A: Molecular \& Integrative Physiology 130:341-51.

Leroy F, Comtet T, Brante A, Leroux C, Riera P. 2012. Can encapsulated embryos of Crepidula fornicata (L.) use extracapsular dissolved organic matter? An experimental study with a ${ }^{13} \mathrm{C}$-enriched amino acid. Journal of Molluscan Studies 78:100-04.

Li H-L, Song L-S, Qian PY. 2008. Cyclic AMP concentration and protein kinase A (PKA) gene expression at different developmental stages of the polychaete Hydroides elegans. Journal of Experimental Zoology 310:417-27.

Liu B, Zhang F, He Y. 1998. Study on induction of metamorphosis in larvae of bay scallop, Argopecten irradians, by some neuroactive compounds. Acta Oceanologica Sinica 20:55-60.

López-Sánchez JA, Maeda-Martínez AN, Croll RP, AcostaSalmón H. 2009. Monoamine fluctuations during the reproductive cycle of the Pacific lion's paw scallop Nodipecten subnodosus. Comparative Biochemistry and Physiology - Part A: Molecular \& Integrative Physiology 154:425-48.

Martinez G, Aguilera C, Campos EO. 1999. Induction of settlement and metamorphosis of the scallop Argopecten purpuratus Lamarck by excess $\mathrm{K}^{+}$and epinephrine: Energetic costs. Journal of Shellfish Research 18:41-46.

Mesías-Gansbiller C, Bendimerad MEA, Román G, Pazos AJ, Sánchez JL, Pérez-Parallé ML. 2008. Settlement behavior of black scallop larvae (Chlamys varia, L.) in response to GABA, epinephrine and IBMX. Journal of Shellfish Research 27:261-64.

Mesías-Gansbiller C, Silva A, Maneiro V, Pazos A, Sánchez JL, Pérez-Parallé ML. 2013. Effects of chemical cues on larval settlement of the flat oyster (Ostrea edulis L.): A hatchery approach. Aquaculture 376-379:85-89.

McDonald JI, Wilkens SL, Stanley JA, Jeffs AG. 2014. Vessel generator noise as a settlement cue for marine biofouling species. Biofouling 30:741-9.

Murthy PS, Venugopalan VP, Nair KVK, Subramoniam T. 1999. Chemical cues inducing settlement and metamorphosis in the fouling oyster Crassostrea madrasensis. Journal of the Indian Institute of Science 79:513-26.

Nicolas L, Robert R, Chevolot L. 1996. Effect of epinephrine and seawater turbulence on the metamorphosis of the great scallop. Aquaculture International 4:293-97.

Nicolas L, Robert R, Chevolot L. 1998. Comparative effects of inducers on metamorphosis of the Japanese oyster Crassostrea gigas and the great scallop Pecten maximus. Biofouling 12: 189-203.

O'Connor MI, Bruno JF, Gaines SD, Halpern BS, Lester SE, Kinlan BP, et al. 2007. Temperature control of larval dispersal and the implications for marine ecology, evolution, and conservation. Proceedings of the National Academy of Sciences of the United States of America 104:1266-71.

O'Connor S, Moltschaniwskyj N, O'Connor W. 2009. Use of neuroactive catecholamines to chemically induce metamorphosis of hatchery-reared flat oyster, Ostrea angasi, larvae. Aquaculture Research 40:1567-77.

O'Connor WA, Dove MC, Finn B, O'Connor SJ. 2008. Manual for the hatchery production of the Sydney rock oyster (Saccostrea glomerata). Fisheries Research Report Series No 20. 50 pages. 
Paine RT. 1971. A short-term experimental investigation of resource partitioning in a New Zealand rocky intertidal habitat. Ecology 52:1096-106.

Penniman JR, Doll MR, Pires A. 2013. Neural correlates of settlement in veliger larvae of the gastropod Crepidula formicata. Invertebrate Biology 132:14-26.

Pires A, Woollacott RM. 1997. Serotonin and dopamine have opposite effects on phototaxis in larvae of the bryozoan Bugula neritina. The Biological Bulletin 192:399-409.

Pires A, Croll RP, Hadfield MG. 2000. Catecholamines modulate metamorphosis in the opisthobranch gastropod Phestilla sibogae. Biological Bulletin 198:319-31.

Qu Y, Li X, Yu Y, Vandepeer M, Babidge P, Clarke S, et al. 2009. The effect of different grading equipment on stress levels assessed by catecholamine measurements in Pacific oysters, Crassostrea gigas (Thunberg). Aquacultural Engineering 40: 11-16.

AQ1 Railkin AI. 2004. Induction and stimulation of settlement by a hard surface. In: Marine Biofouling: Colonization Processes and Defenses. Boca Raton: CRC Press. p 75-102.

Safi KA, Hayden B. 2010. Differential grazing on natural planktonic populations by the mussel Perna canaliculus. Aquatic Biology 11:113-25.

Saito M, Yamasu K, Suyemitsu T. 2012. Binding properties of thyroxine to nuclear extract from sea urchin larvae. Zoological Science 29:79-82.

Sánchez-Lazo C, Martínez-Pita I, Young T, Alfaro AC. 2012. Induction of settlement in larvae of the mussel Mytilus galloprovincialis using neuroactive compounds. Aquaculture 344349:210-15.

Satuito CG, Natoyama K, Yamazaki M. Shimizu K, Fusetani N. 1999. Induction of metamorphosis in the pediveliger larvae of the mussel Mytilus galloprovincialis by neuroactive compounds. Fish Science 65:384-89.

Satuito CG, Bao W, Yang J, Kitamura H. 2005. Survival, growth, settlement and metamorphosis of refrigerated larvae of the mussel Mytilus galloprovincialis Lamarck and their use in settlement and antifouling bioassays. Biofouling 21:217-25.

Shimizu K, Hunter E, Fusetani N. 2000. Localisation of biogenic amines in larvae of Bugula neritina (Bryozoa: Cheilostomatida) and their effects on settlement. Marine Biology 136:1-9.

Siegener R, Chen RF. 2002. Caffeine in Boston Harbour seawater. Marine Pollution Bulletin 44:383-87.

Silveira R, Silva F, Gomes C, Ferreira J, Melo C. 2011. Larval settlement and spat recovery rates of the oyster Crassostrea brasiliana (Lamarck, 1819) using different systems to induce metamorphosis. Brazilian Journal of Biology 71:557-62.

Söylemez S, Murakami K, Strüssmann C, Yokota M, Watanabe S. 2010. Uptake of dissolved free amino acids by spiny lobster Panulirus japonicus phyllosoma larvae. Fisheries Science 76: 437-44.

Stefano GB, Kream RM. 2010. Dopamine, morphine, and nitric oxide: An evolutionary signaling triad. CNS Neuroscience \& Therapeutics 16:e124-37.

Sumin L, Zhenmin B, Hui L, Jianguang F. 2006. Effect of epinephrine on the settlement and metamorphosis of Manila clam larvae. Journal of Ocean University of China 5:141-45.

Tan SH, Wong TM. 1995. Induction of settlement and metamorphosis in the tropical oyster, Crassostrea belcheri (Sowerby), by neuroactive compounds. Journal of Shellfish Research 14:435-38.

Teh CP, Zulfigar Y, Aileen Tan SH. 2010. Comparative effect of L-DOPA on the larval settlement of tropical oysters Crassostrea iredalei and Crassostrea belcheri. Proceedings of the 7th IMT-GT UNINET and the 3rd International PSU-UNS Conferences on Bioscience, Hatyai, Thailand, p 16-18.
Teh CP, Zulfigar Y, Aileen Tan SH. 2011. Influence of serotonin and norepinephrine on induction of larvae settlement of tropical oyster, Crassostrea iredalei. Proceedings of the 4th International Oyster Symposium (ISO4), Tasmania, Australia. 47 pages.

Teh CP, Zulfigar Y, Tan SH. 2012. Epinephrine and L-DOPA promote larval settlement and metamorphosis of the tropical oyster, Crassostrea iredalei (Faustino, 1932): An oyster hatchery perspective. Aquaculture 338:260-63.

Tsyganov VV, Vorontsov DD, Sakharov DA. 2004. Phasic coordination between locomotor and respiratory rhythms in the mollusk Lymnaea: Transmitter-specific modifications. Doklady Biological Sciences 395:103-05.

Urrutia PM, Okamoto K, Fusetani N. 2004. Acetylcholine and serotonin induce larval metamorphosis of the Japanese shortneck clam Ruditapes philippinarum. Journal of Shellfish Research 23:93-100.

Van Alstyne KL, Anderson KJ, Winans AK, Gifford S-A. 2011. Dopamine release by the green alga Ulvaria obscura after simulated immersion by incoming tides. Marine Biology 158:2087-94.

Van Alstyne KL, Anderson KJ, van Hees DH, Fifford S-A. 2013. Dopamine release by Ulvaria obscura (Chlorophyta): Environmental triggers and impacts on photosynthesis, growth, and survival of the releaser. Journal of Phycology 49: 719-27.

Van Alstyne KL, Harvey EL, Cataldo M. 2014. Effects of dopamine, a compound released by the green-tide macroalga Ulvaria obscura (Chlorophyta), on marine algae and invertebrate larvae and juveniles. Phycologia 53:195-202.

Wang G, Liu B, Tang B, Zhang T, Xiang J. 2006. Pharmacological and immunocytochemical investigation of the role of catecholamines on larval metamorphosis by $\beta$-adrenergic-like receptor in the bivalve Meretrix meretrix. Aquaculture 258: 611-18.

Wang X, Bai Y, Huang B. 2010. Effects of chemical cues on larval survival, settlement and metamorphosis of abalone Haliotis asinina. Chinese Journal of Oceanology and Limnology 28:1261-65.

Wei K, Wood AR, Gardner JA. 2013. Seascape genetics of the New Zealand greenshell mussel: Sea surface temperature explains macrogeographic scale genetic variation. Marine Ecology Progress Series 477:107-21.

Wilkens SL, Stanley JA, Jeffs AG. 2012. Induction of settlement in mussel (Perna canaliculus) larvae by vessel noise. Biofouling 28:65-72.

Wyeth RC, Croll RP. 2011. Peripheral sensory cells in the cephalic sensory organs of Lymnaea stagnalis. The Journal of Comparative Neurology 519:1894-913.

Yang B, Qin Y, Shi B, Han G, Chen J, Huang H, et al. 2012. Molecular characterization and functional analysis of adrenergic like receptor during larval metamorphosis in Crassostrea angulata. Aquaculture 366-367:54-61.

Yang B, Pu F, Qin J, You W, Ke C. 2014. Characterization of receptor of activated C kinase 1 (RACK1) and functional analysis during larval metamorphosis of the oyster Crassostrea angulata. Gene 357:294-301.

Yang J-L, Satuito GC, Bao W-Y, Kitamura H. 2008. Induction of metamorphosis of pediveliger larvae of the mussel Mytilus galloprovincialis Lamarck, 1819 using neuroactive compounds, $\mathrm{KCl}, \mathrm{NH}_{4} \mathrm{Cl}$ and organic solvents. Biofouling 24:461-70.

Yang J-L, Li S-H, Li Y-F, Liu Z-W, Liang X, Bao W-Y, et al. 2013. Effects of neuroactive compounds, ions and organic solvents on larval metamorphosis of the mussel Mytilus coruscus. Aquaculture 396:106-12.

Yang J-L, Li W-S, Liang X, Li Y-F, Chen Y-R, Bao W-Y, et al. 2014. Effects of adrenoceptor compounds on larval metamorphosis of the mussel Mytilus coruscus. Aquaculture 426427:282-87. 
Young T, Alfaro AC, Robertson J. 2011. Effect of neuroactive compounds on the settlement of mussel (Perna canaliculus) larvae. Aquaculture 319:277-83.

Yu X, He W, Gu JD, He M, Yan Y. 2008. The effect of chemical cues on settlement of pearl oyster Pinctada fucata martensii (Dunker) larvae. Aquaculture 277:83-91.

Zetsche E-M, Meysman FJR. 2012. Dead or alive? Viability assessment of micro- and mesoplankton. Journal of Plankton Research 34:493-509.

Zhao B, Zhang S, Qian PY. 2003. Larval settlement of the silveror goldlip pearl oyster Pinctada maxima (Jameson) in response to natural biofilms and chemical cues. Aquaculture 220: 883-901.

Zhou Z, Wang L, Shi X, Zhang H, Gao Y, Wang M, et al. 2011. The modulation of catecholamines to the immune response against bacteria Vibrio anguillarum challenge in scallop Chlamys farreri. Fish \& Shellfish Immunology 31:1065-71.

Zhu W, Mantione KJ, Shen L, Cadet P, Esch T, Goumon Y, et al. 2005a. Tyrosine and tyramine increase endogenous ganglionic morphine and dopamine levels in vitro and in vivo: Cyp2d6 and tyrosine hydroxylase modulation demonstrates a dopamine coupling. Medical Science Monitor 11:BR397-404.

Zhu W, Mantione KJ, Shen L, Stefano GB. 2005b. In vivo and in vitro L-DOPA and reticuline exposure increases ganglionic morphine levels. Medical Science Monitor 11:MS1-5.

Zimmer-Faust RK, Tamburri MN. 1994. Chemical identity and ecological implications of a waterborne, larval settlement cue. Limnology and Oceanography 39:1075-87.

Editorial responsibility: Eric Thompson 